\title{
WALTER LAFEBER \\ THE AMERICAN AGE: U.S. FOREIGN POLICY AT HOME AND ABROAD
}

Publisher: W. W. Norton \& Company. New York. 1994, 759 s., ISBN-13: 9780393964745 (Dil: İngilizce)

Shatlyk AMANOV ${ }^{[*]}$

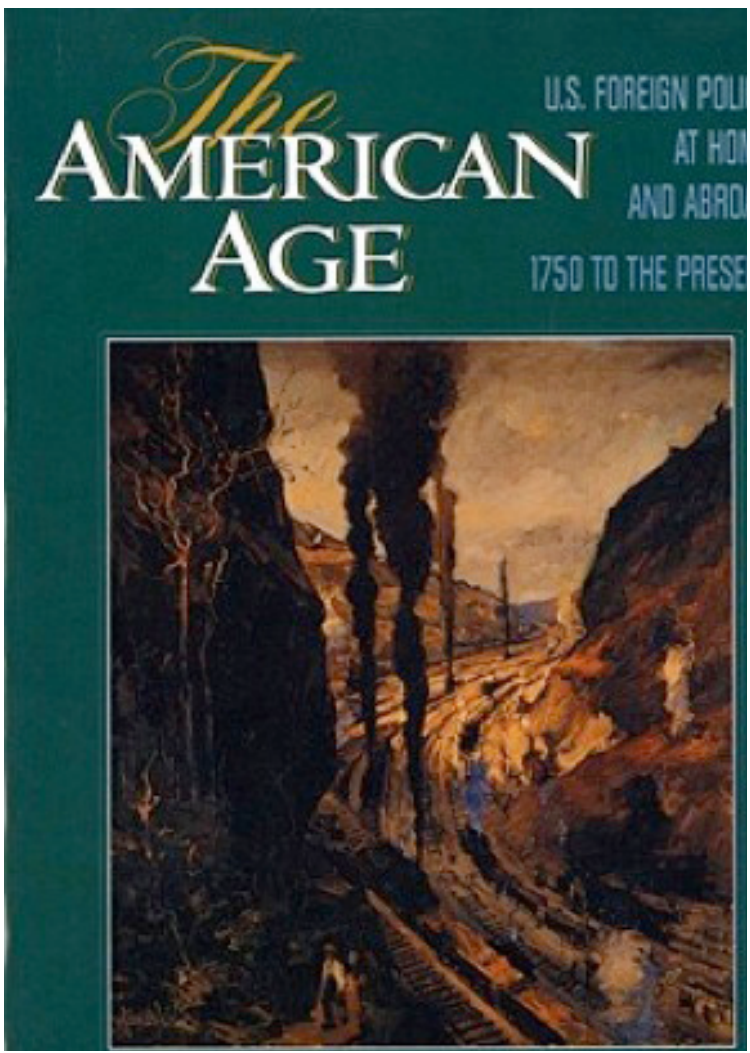

JEL Sinıflandirmas1: F50, F59

Yrd. Doç. Dr., Melikşah Üniversitesi, Siyaset Bilimi ve Uluslararası İlişkiler Bölümü (İng.), Kayseri, e-posta: shatlyk@meliksah.edu.tr 
Amerikan dış ilişkiler tarihinin en saygın isimlerinden biri olan Walter LaFeber (Cornell Üniversitesi - Tarih Bölümü), The American Age: United States Foreign Policy at Home and Abroad isimli kitabında okurlara Amerika Birleşik Devletleri'nin diplomasi tarihine geniş bir pencereden bakma imkânı sunmaktadır. Kitap, kolonyal dönemden başlayarak Başkan Bill Clinton'a kadarki - yani neredeyse ABD'nin kuruluşundan günümüze kadar geçen iki asrı aşkın bir dönemin - Amerikan dış politikasının [tutarlı] ve [çözümleyici] bir “kavramsal analizi"ni ortaya koymaktadır.

Yazar kitabını, insan doğasına ilişkin skeptik düşünceleriyle Amerikan tecrübesine yönelik ümitlerini barıştırmaya çalışan ünlü devlet adamı John Adams'ın bir [Amerikan] devlet adamının [ve/veya dışişleri bakanının] genel olarak sahip olması gereken özelliklerine ilişkin görüşlerinden alıntı yaparak açmaktadır. Buna göre, söz konusu görevi üstlenecek kişinin klasik eğitim, genel tarih, kadim - çağdaş ve özellikle Fransa, İngiltere, Hollanda ve Amerikan tarihine ilişkin bilgiye sahip olması gerekmektedir. Etiğin prensiplerini, doğa ve ulusların kanunlarını, yasama ve yürütmeyi, Avrupa kamu hukukunu ve günümüze kadar ulusların ve dünyanın kaderini tayin etmiş olan büyük şahsiyetlere ait mektupları, hatıraları ve tarihi yazıları çok iyi bilmelidir. Ayrıca o, aktif, dikkatli ve çalışkan, dürüst ve özgür ruhlu olmalıdır; şahsi hırs ve çıkarları yerine ülkesinin çıkarlarını ön planda tutmalıdır. LaFeber'in aynı sayfada yer verdiği ve Başkan John F. Kennedy'ye ait bir diğer alıntısı da dış politika meselelerine verilmesi gereken önemi göstermesi açısından ilginçtir: "İç meseleler sadece seçimleri kaybettirebilir; dış politika meseleleri ise hepimizi mahvedebilir."

Kitabın büyük bir kısmı İspanyol - Amerikan Savaşından sonraki dönem üzerinde yoğunlaşmaktadır. Amerikan siyasi tarihindeki bütün önemli gelişmeler ve olaylar dikkatle incelenmesine rağmen Lafeber, ABD dış politikasına nüfuz eden üç ana eğilim tespit etmektedir:

a) Genişleme eğilimi: 1750'li ve 1990'lı yıllar arasında Amerikanın dışa açılımını sağlayan teritoryal ve ticari anlamda bir genişleme. Yayılmacılık, özellikle John Quincy Adams (1767 - 1848) tarafından ateşli bir şekilde savunulmuştur (s. 76). Ona göre ABD ile Kuzey Amerika arasında bir fark yoktur; yani her ikisi de [identical]dir.

b) Gücün merkezileşmesi: 1890 sonrasında "gücün” - özellikle yürütme (hükümet) gücünde meydana gelen - istikrarlı bir şekilde merkezileşmesi süreci. LaFeber'a göre bu süreç, sadece insan doğasına referansla tanımlanan bir "güç mücadelesi”ne indirgenerek 
açıklanamaz; bunun yanı sıra yazar Amerikan kamuoyunun 19. yüzyıldan itibaren arzu ettiği türden bir dış politikanın, ancak güçlü bir "başkanlık sistemi” ile etkin șekilde uygulanabileceği gerçeğinin de dikkate alınması gerektiğini vurgulamaktadır.

c) Yalnızcılık eğilimi: Yazara göre "izolasyonizm” (yalnızcılık), Amerikan tarihinde dünya siyasetinden çekilmeyi değil, aksine maksimum düzeyde bir "hareket özgürlüğünün" (s.22) sürdürülmesini öngören bir eğilimi temsil etmektedir. Buna paralel olarak, içeride "bireyciliğe" (individualism - s. 97) inandığını ileri süren Amerikalılar, dış politikada da sıklıkla aynı unsura bağlı kalarak (ss. 336 - 337 ve ss. 362 - 363.) hareket etmektedirler.

Lafeber, ayrıca, 1850 - 1914 yılları arasındaki "geçiş" (transitional) döneminin, Amerikan siyasi kültürüne, tarihine ve düşünsel yapısına etkileri açısından çok önem arz ettiğini iddia etmektedir. Nitekim bu dönem Amerikalıların demokrasi, Monroe Doktrini, Anayasa ve özellikle "Devrim"e ilişkin tutumlarının büyük bir dönüşüm geçirdiği ve çağdaş Amerikan dış politikasının şekillenmeye başladığı bir dönemdir. Burada yazarın söz konusu (I. Dünya Savaşı öncesi) dönem ile, etnik çatışmaların ve bölgesel istikrarsızlıkların egemen olduğu (Balkanlar ve Doğu Avrupa'da görüldüğü gibi), güçlü Japonya'nın ve birleşmiş Almanya'nın yükseldiği ve oldukça gelişmiş - ve siyasi açıdan da bir o kadar yıkıcı - teknoloji ve iletişim araçlarının ortaya çıktığı 1989 - 1993 yılları arasında benzerlik kurması önemlidir.

Yazar, Amerikan dış politikasını doğru anlayabilmek için onun yerel - iç meselelerle olan yakın ve özel ilişkisinin çok iyi çözümlenmesi gerektiğine inanmaktadır. Lafeber'in çalışması bu anlamda oldukça açıklayıcı bir çerçeve sunmaktadır. Her şeyden önce, Amerikan düşünce yapısını belirleyen ve daha spesifik anlamda Amerikan karar vericilerini yönlendiren bazı [kurucu] kavramlar, kuruluşundan günümüze kadarki Amerikan dış politika eğilimlerinin anlaşılması açısından önemlidir. Bu kavramlardan en önemlisi [şüphesiz, S.A.] "Amerikan ayrıcalıklılığı"dır (American exceptionalism). Amerikan ayrıcalıklılığı anlayışı, bütün uzantılarıyla birlikte, kitabın tüm bölümlerine yansımış bulunmaktadır. Bu kavram, Amerikanın siyasi - kültürel yönlerden diğer ülkelerden farklı ve çoğu zaman da "üstün" olduğu inancına dayanmaktadır. Böylesi bir inancın izlerine, Amerikanın henüz İngiltere'nin sömürgesi olduğu dönemlerde ve özellikle İncil'deki “tepedeki şehir" [city on the hill - ss. 8-9] imajında rastlamak mümkündür. Bir diğer kurucu kavram ise, Amerikalıların kendi değerlerini tüm dünyaya yayma yükümlülüklerinin olduğuna ısrarla inanmalarıdır. Bu kavramsal çerçevenin, dünyadaki Amerikan 
liderliğinin korunması ve sürdürülmesi için gerekli teorik ve pratik zemini hazırladığı öne sürülebilir (S.A).

Yazara göre Amerikalılar, Eski Dünyanın zorlama ve kısıtlamalarından bağımsız bir şekilde "misyon ve para" [mission and money, s. 5] şeklinde formüle edilen hayallerini gerçekleştirmenin tadını çıkarırken, bu, onlara süper güç olmaya giden yolun kapılarını da açmaktaydı.

Diğer taraftan kitabın başlığında kullanılan "Age" kelimesi bilinçli olduğu kadar tutarlı bir seçimin yapıldığını göstermektedir. Lawrence S. Kaplan'ın (Kent State University) haklı olarak belirttiği gibi "American Age" terimi - "American Century" teriminin aksine - Amerikan tarihinin büyük bir bölümünü karakterize edebilir. Profesör Thomas A. Bailey'in de gözlemlediği gibi ABD bağımsızlığını ilan ettiği 1776 yılından itibaren bir dünya gücü olarak ortaya çıkmıştır. Diğer bir ifadeyle "Amerikan Çağı" ta o dönemden itibaren başlamıştır. Zira o dönemde bile Amerika nüfusu, kapladığı alanı, ekonomik gücü, doğal kaynaklarının zenginliği ve özellikle de "hırs"ı bakımından dönemin Avrupalı büyük güçleri ile boy ölçüşebilecek seviyedeydi.

Yazar, Amerikalıların toplumsal eğilimlerinin ve içerideki davranışlarının dışarıdaki tutumlarını da yansıttığına inanmaktadır ve bu bağlamdaki yorumlar genellikle yerel olaylara (sinema ve spor dahil) odaklanarak açıklanmaktadır. Yani kitabın farklı yerlerinde iç gelişmelere ve/veya olaylara vurgu yapılırken aslında bunların ABD'nin uluslararası müdahalelerini ve angajmanını da yansıttığı ileri sürülmektedir. Amerikan hayatı ve halk kültürüne ilişkin yorumları belki bazı okuyucular tarafindan kabul edilmeyebilir ancak yazarın, toplumsal ve diplomatik tarihi bu kadar birbirine yakın bir şekilde irtibatlandırma çabası takdir edilecek bir husustur. Diğer taraftan mizahi ifadeler kitaba ayrı bir renk katmaktadır (örnek için s. 462).

Yazar anlatımını, hem değindiği konuları canlandıran hem de çok iyi izah eden farklı referanslar ile desteklemektedir. Yani yazarın kullandığı kaynaklar oldukça çeşitlilik arz etmektedir. Özellikle 1980'lerde yayınlanmış olan ve Amerikan dış politika tarihi konusunda önemli sayılan birçok kitap ve makalenin ayrıntılı bir listesi okuyucunun dikkatine sunulmaktadır. Her bölümün sonunda kullanışlı bir bibliyografik kaynakça yer almaktadır. Kitabın farklı bölümlerinde kullanılan fotoğraflar, grafikler, haritalar, çizelgeler ve karikatürler okuyucuya çözümleyici bir bakış açısı sunmaktadır. Geniş okuyucu kitlesini cezbeden daha da önemli şey ise, Lafeber'in Amerikan diplomasi tarihi ile ilgili edebiyata olan vukufiyetidir. Amerikan kamuoyunun kaygılarını ve onların dış politikadaki eğilimlerini yansıtan filmler, televizyon programları, sinema, müzik ve diğer medya araçları, LaFeber'in sık sık atıf 
yaptığı referanslar arasında yer almaktadır. Aslında böylesi bir metot kitabı daha akıcı hale getirmekte ve olayları tarihsel ve siyasi paradigmaların yanı sıra kültürel, toplumsal ve psikolojik boyutuyla da değerlendirme firsatı vermektedir. Kitle iletişim araçları (kitabın kaleme alındığı dönemi göz önünde bulundurduğumuzda özellikle televizyon ve gazete) vatandaşların dış politika tercihlerini her geçen gün daha fazla etkilemektedir: iletişim ve ulaşımdaki son teknolojik gelişmeler [bilgi]yi evlere kadar taşımış, kamuoyunun oluşumunu ve mevcut sistemi çok derinden etkilemiştir. Bireylerin günlük yaşantılarının, politik ve ekonomik tercihlerinin devlet dış1 etkileşime uğradığı günümüzde (Amerikan toplumu bağlamında), LaFeber'in değişik referanslara başvurarak anlatımını zenginleştirmesi, konuyu daha rasyonel, açıklayıcı ve çözümleyici bir temele oturtmasını sağlamaktadır.

Kitabı farkl1 kılan özelliklerden bir tanesi de LaFeber'in, reel-politiğin egemen olduğu bir dünyada "Amerikan tutumu"nun formüle edilmesi için "geçmiş"e, daha doğrusu "Kurucu Ataların" (Founding Fathers) dönemine göz atması ve atıflarda bulunmasıdır. Nitekim kitabın ilk ve son sayfalarındaki özgün alıntılar ve yorumlar bu tespiti doğrulamaktadır. Texas Tech Üniversitesinden James W. Harper'e göre "revizyonist okul"un en önemli yazarlarından biri olan Lafeber, Amerikalıları kendi tarihlerini iyi ögrenmeye davet etmekte, hatta zorlamaktadır; onları (yani Amerikalıları), James Madison ve diğer Kurucu Atalar tarafindan oluşturulan tarihi derslerden ibret almaları konusunda uyarmaktadır. Aslında bu tespitler, Lafeber'in, ABD'nin önlenmesi çok zor olan bir küresel inişe geçtiğine inand1ğını da açıklamaktadır (S.A).

Yazarın kişisel yargıları ve görüşleri, kullandığı üsluba göre daha az belirgindir. Anlatımı ikna edicidir. Ancak herkesin kabul ettiği gibi, hem aşırı yüzeysel olmayan hem de polemiklere kapalı bir eser yazmak oldukça zor bir görevdir. Neredeyse 800 sayfayı aşkın bir kitapta, ufak da olsa bazı eksikliklerin bulunması kaçınılmazdır. Örneğin 1960 yılında patlak veren U-2 sorununun, "ABD - Sovyetler Birliği ilişkilerinde 1945’ten beri görülen en parlak dönemi” (s. 543) sekteye uğrattığı görüşü tartışmalıdır. Nihai tahlilde kitap Amerikan dış ilişkiler tarihine ilgi duyan akademisyen, araştırmacı ve öğrencilerin yanı sıra genel okuyucu kitlesinin de rahatlıkla istifade edebileceği - doyurucu içeriğiyle - vazgeçilmez bir başvuru kaynağı olarak değerlendirilebilir.

LaFeber kitabını, meşhur Amerikalı muhafazakâr Henry Adams'ın çağdaş topluma ve insan rolüne ilişkin [kötümser] sözleriyle ve ayrıca James Madison'un Amerikanın parlak geleceğine ilişkin [ihtiyatll] ve [iyimser] görüşleriyle kapat1yor (s. 778-779). 